\title{
Root Growth and Nitrogen Utilization of a Leek Crop and an Undersown Catch Crop.
}

\author{
K.L. Nielsen and K. Thorup-Kristensen \\ 1) Department of Horticulture, Danish Institute of Agricultural Sciences, Kirstinebjergvej 10, DK-5792 Aarslev, \\ Denmark,kai.nielsen@agrsci.dk
}

Key words: Allium porrum, Cichorium intybus, cover crops, nitrate leaching, root growth, soil nitrate depletion

\begin{abstract}
After its late harvest a leek (Allium porrum) crop will normally leave large quantities of nitrogen $(\mathrm{N})$ in the soil which may be subject to leaching. A possible method to reduce $\mathrm{N}$ leaching losses is to establish a catch crop before the harvest of the leek crop. It was the aim of this study to investigate the effects of incorporating a catch crop in a leek crop with minimal competition and to monitor how root growth affected $\mathrm{N}$ availability across soil depths at different distances between catch and leek crop rows. To reduce competition between both crops leek was planted at 0.5 and $0.75 \mathrm{~m}$ row distances and chicory (Cichorium intybus) as a catch crop at an interrow spacing of $0.75 \mathrm{~m}$. Minirhizotron glass tubes were inserted in the middle of the interrow spaces (with or without catch crop established in mid July) and in the leek row. Leek roots grew to a depth of about $0.4 \mathrm{~m}$ by mid October with a high root density directly below the leek row but did not extend growth to the centre of the $0.75 \mathrm{~m}$ interrow. At the same time the catch crop had extended its roots to a depth of at least $1.25 \mathrm{~m}$ and was exploring the full width of the $0.75 \mathrm{~m}$ interrow with some roots even below the leek rows. The results show that it is possible to establish a catch crop in leek thereby depleting soil $\mathrm{N}$ and reduce the risk of $\mathrm{N}$ leaching without jeopardising crop yield.
\end{abstract}

\section{Introduction}

To reduce $\mathrm{N}$ leaching catch crops can be established in autumn to take up excess $\mathrm{N}$ left over by major crops. After the harvest of leek normally large quantities of $\mathrm{N}$ remain in the soil whereby the crop is usually harvested too late to allow the successful establishment of a catch crop thereby preventing $\mathrm{N}$ leaching. A possible alternative would be to establish the catch crop before the harvest of leek. To avoid negative effects on leek yield it is important to minimise competition with the catch crop.

Nitrate moves rather freely with the flow of water in the soil, and when present in deeper soil layers it will have to be transported from there by plant roots to become available for the succeeding crop. Although catch crops have been studied intensively, only a few studies have dealt with roots (Lainé et al,. 1993; ThorupKristensen, 1993, 2001; Voss et al., 1998). Of the parameters compared, rooting depth was found to be closely related to $\mathrm{N}$ depletion (Thorup-Kristensen, 1993). None of the measurements of plant dry matter production and $\mathrm{N}$ content aboveground or root parameters in the upper soil layers were closely related to subsoil nitrate depletion (Thorup-Kristensen, 2001). Deep rooted catch crops will have access to a larger soil volume and can therefore deplete parts of the soil volume not available to more shallow rooted crops.

This study aimed at investigating the effects of incorporating a catch crop in leek with minimal competition and to monitor the effects of root growth on available soil $\mathrm{N}$ at various depths and distances between crop rows.

\section{Materials and methods}

The experiment was conducted in the fall of 1997 at

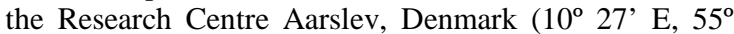
$18^{\prime} \mathrm{N}$ ) on a typic Agrudalf soil. Leek had been planted by end May 1997.

To reduce competition between both crops leek had been planted in May 1997 at alternating rows spaced 0.5 and $0.75 \mathrm{~m}$ and chicory (Cichorium intybus) as a catch crop at the $0.75 \mathrm{~m}$ interrow spacing in mid July. Minirhizotrons glass tubes (of $70 \mathrm{~mm}$ outer diameter and $1.5 \mathrm{~m}$ length) were inserted in each plot by the end of May, prior to the planting of leek. They were placed in the centre of the leek row (reference row, position $0 \mathrm{~m}$ ), between leek rows (position $0.25 \mathrm{~m}$ ) and in the centre of the catch crop row (position $0.375 \mathrm{~m}$ ). The minirhizotrons were installed at an angle of $30^{\circ}$ from vertical, reaching a depth of approximately $1.25 \mathrm{~m}$. Rooting depth was monitored at 14 day intervals and at 7 day intervals between mid August and late October. Root intensity (defined as the number of root intersections per $\mathrm{cm}$ along a $40 \mathrm{~mm}$ vertical and a $40 \mathrm{~mm}$ horizontal line painted on the minirhizotron tubes) was measured on the tubes down to $1.25 \mathrm{~m}$ by mid October. Similarly $\mathrm{N}_{\min }$ was measured mid October at four depth intervals $(0-0.25 \mathrm{~m}$, $0.25-0.50 \mathrm{~m}, 0.50-0.75 \mathrm{~m}$ and $0.75-1 \mathrm{~m})$. Temperature sums (day ${ }^{\circ} \mathrm{C}$ ) were calculated as the sum of daily average temperatures.

\section{Results and discussion.}

Significant differences in root depth penetration were found between leek $\left(0.197 \mathrm{~mm} \text { [day }{ }^{\circ} \mathrm{C}\right]^{-1}$ equivalent to $\left.2.9 \mathrm{~mm} \mathrm{day}^{-1}\right)$ and the catch crop $\left(1.31 \mathrm{~mm}\left[\text { day }{ }^{\circ} \mathrm{C}\right]^{-1}\right.$ 
equivalent to $23.8 \mathrm{~mm}$ day $^{-1}$ ). This led to significant differences in rooting depth over time with leek reaching a maximum depth of about $0.4 \mathrm{~m}$ before harvest and the catch crop exceeding the depth of the minirhizotrons by late September (Figure 1). The presence of the catch crop did not lead to reductions in yield (number and dry weight of leeks $\mathrm{m}^{-2}$ ) and quality (number of usable leek $\mathrm{m}^{-2}$ ) of the leek crop (data not shown).

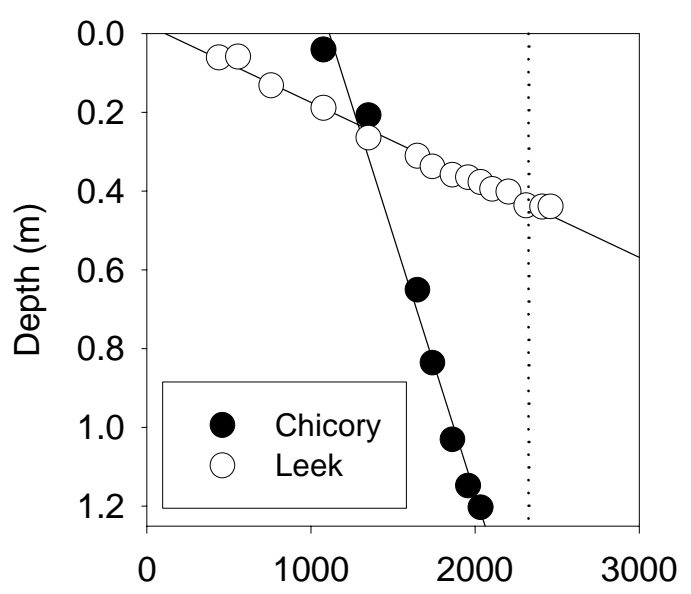

Temperature sum from leek planting (day ${ }^{\circ} \mathrm{C}$ )

Figure 1. Rooting depth of leek (Allium porrum) and Chicory (Chicorium intybus) in a typic Agrudalf soil. Time is shown as cumulative temperature from May 25 (planting of leek). The vertical dotted line indicates mid October when root intensity was measured. Linear regressions for depth penetration of leek. Open symbols indicate the rooting depth $(\mathrm{m})$ of leek $\left[1.97 \times 10^{-4} \times\right.$ temperature sum from planting $\left.-0.0221 ; r^{2}=0.989\right]$ and and closed symbols that of chicory $\left[1.31 \times 10^{-3} \times\right.$ temperature sum from sowing $\left.-0.462 ; r^{2}=0.979\right]$.

Mid October leek roots grew to a depth of about 0.4 $\mathrm{m}$ with high root intensity below the leek row $(0 \mathrm{~m}$ from the reference row; Figure 2A), but did not extend its roots to the centre of the $0.75 \mathrm{~m}$ interrow $(0.375 \mathrm{~m}$ from the reference row; Figure 2A, without chicory). At the same time the catch crop had reached a rooting depth of more than $1.25 \mathrm{~m}$.

Mid October the nitrate content under the leek row $(0$ $\mathrm{m}$ from the reference row, Figure $2 \mathrm{~B}$, without chicory) was still very high, with $4-6 \mathrm{mg} \mathrm{kg}^{-1}$ particularly below $0.5 \mathrm{~m}$, whereas the catch crop depleted the full width of the $0.75 \mathrm{~m}$ center row for nitrate $(0-2 \mathrm{ppm})$ and also reduced the nitrate concentration under the leek row $(2-$ $4 \mathrm{ppm}$, Figure 2B, $0 \mathrm{~m}$ from the reference row, with chicory).

Our data confirm the results of Thorup-Kristensen (1993, 2001), that rooting depth and root intensity are closely related to nitrogen depletion. The results allow the conclusion that it is possible to establish an efficient catch crop in leek to deplete the soil of residual $\mathrm{N}$ thereby reducing the risk of leaching losses.

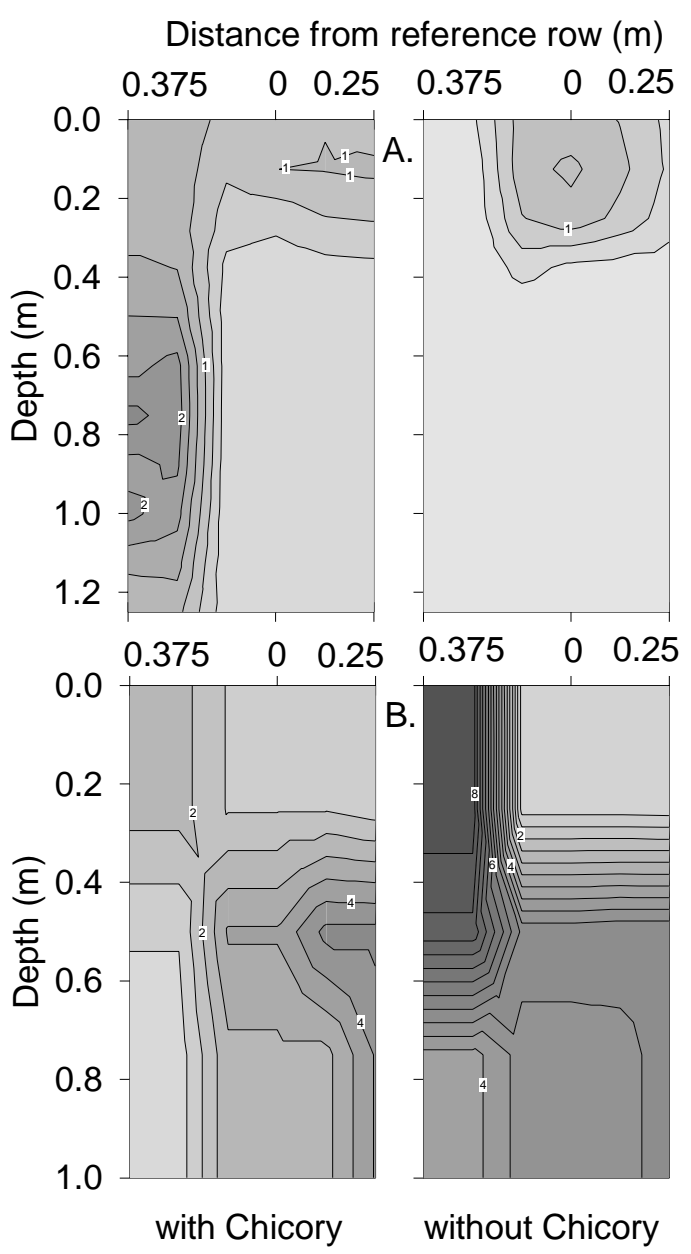

Figure 2. Spatial distribution of (A) root intensity (root intersections $\mathrm{cm}^{-1}$ line on the minirhizotrons) and (B) soil nitrate- $\mathrm{N}\left(\mu \mathrm{g}\right.$ nitrate $\mathrm{g}^{-1}$ soil dry matter) of leek mid October with (left) and without (right) chicory as a catch crop. Measurements were taken under a leek row $(0 \mathrm{~m}$ from the reference row) between leek rows $(0.25 \mathrm{~m}$ from the reference row) and under the catch crop $(0.375 \mathrm{~m}$ from the reference row).

\section{References}

Lainé P, Ourry A, Macduff J, Boucard J and Salette J 1993. Phys. Plant. 88, 85-92.

Thorup-Kristensen, K. 1993. Acta Agric. Scand., Sect. B, Soil Plant Sci. 43, 58-64

Thorup-Kristensen, K. 2001. Plant Soil. In press

Vos J, van der Putten PEL, Hussein MH, van Dam AM and Leffelaar PA 1998. Plant Soil 201, 149-155. 
